\title{
EFFECTS OF EGG BATH AND DAILY REMOVAL OF DEAD EGGS ON HATCHING SUCCESS AND PRODUCTION OF STAGE 2 JUVENILES DURING ARTIFICIAL INCUBATION IN NOBLE CRAYFISH (ASTACUS ASTACUS L.)
}

\author{
T. POLICAR (1), P. KOZÁK (1), J. MARTÍN (2)
}

(1) University of South Bohemia in České Budějovice, Research Institute of Fish Culture and Hydrobiology at Vodňany, Zátiší 728/II, 38925 VODŇANY, Czech Republic. E-Mail: policar@vurh.jcu.cz

(2) Ecology Area, Physics Department, Extremadura University, Avda. Elvas s/n, Badajoz 06071, Spain.

\section{ABSTRACT}

The effects of egg bath (iodine-detergent preparation) and daily removal of dead eggs on hatching success and production of juveniles in stage 2 were investigated during a short (sixteen days) artificial incubation (AI) of noble crayfish eggs.

At the beginning of $\boldsymbol{A l}$, eggs were in phase XII (pulsating heart appearance) and were incubated in 18 polyethylene 1 liter jars (100 eggs/jar, egg density 4.5 eggs. $\mathrm{cm}^{-2}$ ). Six different treatments were tested during $\mathbf{A l}$ :

- C: control group without removal of dead eggs and egg bath;

- R: daily removal of dead eggs without egg bath;

- R-LB: daily removal of dead eggs, low frequency of egg bath (once every five days);

- R-FB: daily removal of dead eggs, frequent egg bath (once every three days);

- LB: without removal of dead eggs, with low frequency of egg bath;

- FB: without removal of dead eggs, with frequent egg bath.

Egg bath was performed by iodine-detergent preparation Jodisol (dose $2 \mathrm{ml}^{. \mathrm{I}^{-1}}$ and exposition time 2 minutes).

Results showed a better hatching rate after removing dead eggs rather than using the egg bath. Three treatments (R; R-LB; R-FB) showed significantly better survival rates in stage $1(86.3 \pm 5.4 \%)$ and $2(84.2 \pm 5.4 \%)$ than control $(74.3 \pm 0.9 \%$ and $73.3 \pm 0.5 \%$, respectively). Two treatments ( $\mathrm{LB}, \mathrm{FB})$ showed no statistically different survival rate in stage 1 and $2(82.5 \pm 5.5$ and $80.7 \pm 5.3 \%$, respectively) than the other treatments.

After $\boldsymbol{A}$, juveniles from all treatments were reared under controlled conditions. At the end of rearing period, juveniles reached a survival rate of $64.1 \pm 0.5 \%$ with mean body length of $22.0 \pm 1.6 \mathrm{~mm}$ and mean body weight of $266.0 \pm 50.9 \mathrm{mg}$. Negative effects of $\boldsymbol{A l}$ on growth and survival of juveniles were not evidenced.

Key-words: Astacus astacus, artificial incubation, jar, juvenile production. 


\section{EFFICACITÉ DU BAIN DES CEUFS ET DE L'ENLÈVEMENT JOURNALIER DES CEUFS MORTS SUR L'ÉCLOSION ET LA PRODUCTION DES JUVÉNILES AU STADE 2 PENDANT L'INCUBATION ARTIFICIELLE DE L'ÉCREVISSE À PATTES ROUGES (ASTACUS ASTACUS L.)}

\section{RÉSUMÉ}

L'efficacité du bain des œufs dans une solution d'iode - Jodisol, solution à 2 ml.l-1 - et de l'enlèvement journalier des œufs morts sur l'éclosion et la production des juvéniles au stade 2 a été observée au cours de la période courte (16 jours) de l'incubation artificielle (IA) d' œufs de l'écrevisse à pattes rouges.

Au début de IA des œufs étaient à la phase XII (apparition de pulsations du cœur) et leur incubation s'est déroulée dans 18 flacons polyéthyléniques d'un litre (100 œufs/flacon, densité de 4,5 œufs. $\mathrm{cm}^{-2}$ ). Six traitements différents ont été examinés pendant $\boldsymbol{I} \boldsymbol{A}$ :

C : groupe témoin; pas d'enlèvement des œufs morts ; pas de bain des œufs ;

$\mathbf{R}$ : enlèvement journalier des œufs morts ; pas de bain des œufs ;

R-LB : enlèvement journalier des œufs morts ; fréquence de bain des œufs : une fois tous les cinq jours ;

R-FB : enlèvement journalier des œufs morts ; fréquence de bain des œufs : une fois tous les trois jours ;

LB : pas d'enlèvement des œufs morts, fréquence de bain des œufs diminuée ;

FB : pas d'enlèvement des œufs morts, fréquence de bain des œufs augmentée.

Le bain des œufs a été réalisé avec la solution d'íode - Jodisol (une dose est 2 ml.I- ${ }^{1}$, une durée de bain est 2 minutes).

Les résultats démontrent que l'enlèvement des œufs morts est plus important pour le succès de l'éclosion que leur bain. Troix expériences ( $R$; R-LB ; R-FB) pendant lesquelles l'enlèvement des œufs morts a été réalisé chaque jour (pas de bain des œufs) montrent que la survie des œufs, des juvéniles au stade $1(86,3 \pm 5,4 \%)$ et au stade 2 $(84,2 \pm 5,4 \%)$ est plus grande en comparant avec le groupe témoin $(74,3 \pm 0,9 \%$ au stade 1 et $73,3 \pm 0,5 \%$ au stade 2 ). Deux expériences (- LB, $-F B$ ) pendant lesquelles des œufs ont été baignés et l'enlèvement des œufs morts n'a pas été réalisé ne montrent pas de grande différence statistique de survie des juvéniles au stade 1 et au stade 2 $(82,5 \pm 5,5$ et $80,7 \pm 5,3 \%)$ en comparaison avec les autres expériences.

Après l'incubation artificielle, les juvéniles de toutes les expériences ont été élevés en conditions artificielles. A la fin de la période d'élevage, les juvéniles ont gagné une longueur de 22,0 $\pm 1,6 \mathrm{~mm}$ et un poids de 266,0 $\pm 50,9 \mathrm{mg}$. Un taux de survie a été $64,1 \pm 0,5 \%$. Aucun effet négatif de l'incubation artificielle n'a été observé.

Mots-clés: Astacus astacus, écrevisse à pattes rouges, incubation artificielle, flacon, production de juvéniles.

\section{INTRODUCTION}

Astacid crayfish have long embryonic development (6-9 months) in natural conditions (REYNOLDS et al., 1992). During long embryonic development, hatching success has not been ensured (CARRAL et al., 2003). Frequent post-spawning egg losses have been mainly caused by aggressive interactions among animals and poor egg attachment (CELADA et al., 1988; TAUGBØL and SKURDAL, 1990a, b; POLICAR et al., 2004). High 
mortality of eggs was observed by CARRAL et al. (1988, 1992, 2004), MATTHEWS and REYNOLDS (1995), PÉREZ et al. (1998ab, 1999) and CELADA et al. (2004) during the last stages of development.

Many authors described and used $\boldsymbol{A l}$ of crayfish eggs under controlled conditions (MASON, 1977b; CUKERZIS et al., 1978; RHODES, 1981; CUKERZIS, 1988, 1989; CARRAL et al., 1992, 2004; MATTHEWS and REYNOLDS, 1995; JÄRVENPÄÄ and ILMARINEN, 1995; PÉREZ et al., 1998ab, 1999, 2003; CELADA et al., 2000, 2001, 2004) in order to improve survival rate.

Various facilities were used to carry out Al: Zuger jar (STREMPEL, 1973; KÖKSAL, 1988 and CUKERZIS, 1988); vertical incubator designed for salmonid eggs (MASON, 1977b); apparatuses based on a moving tray (JÄRVENPÄÄ and ILMARINEN, 1995); special flow incubators for crayfish in a semi-recirculation water system (CARRAL et al., 1988, 1992) and in a flow-through system (RHODES, 1981; MATTHEWS and REYNOLDS, 1995; CARRAL et al., 2004; CELADA et al., 1988, 2004; PÉREZ et al. 1998ab, 1999).

Two ways of $\boldsymbol{A l}$ are described, the so-called short and long artificial incubations. First method of $\boldsymbol{A l}$ covers only a short period (several days) of the final embryo development and before eggs remain attached to the maternal pleopods for several months (CUKERZIS et al., 1988). Second type of $\boldsymbol{A} \boldsymbol{I}$ takes several months and eggs are removed at earlier embryonic phases (CARRAL et al., 1992, 2004; PÉREZ et al., 1998ab, 1999, 2003; CELADA et al., 2000, 2001, 2004). Short $\boldsymbol{A} \boldsymbol{l}$ is less demanding for energy, time and space compared to long $\boldsymbol{A} \boldsymbol{l}$ but incubated eggs are more dependent on maternal care and outdoor conditions, where hatching success is unwarranted for long time (CUKERZIS, 1988).

Generally, $\boldsymbol{A l}$ has several advantages such as a reduced dependence on females and minimizes maternal egg brooding problems such as egg losses (PÉREZ et al., 1999). $\boldsymbol{A} \boldsymbol{I}$ techniques provide control on ambient conditions such as water quality, elimination of predators and the reduction in transmission of pathogens from broodstock to offspring. During $\boldsymbol{A l}$, stage-2 juvenile production is obtained under controlled conditions making their subsequent collection easier (CARRAL et al., 2003). Incorporation of artificial breeding techniques into crayfish farms could reduce food, energy and space expenses (CARRAL et al., 1992; GONZÁLEZ et al., 1993), since eggs can be incubated in high densities (JÄRVENPÄÄ and ILMARINEN, 1995).

Egg mortalities were found during the whole $\boldsymbol{A l}$ (CELADA et al., 2001) but the majority of eggs were dead between the eyed stage and juvenile stage 2 (CARRAL et al., 2004). Most of the egg mortalities coincide with terminal stages of embryogenesis (increased metabolic activities and the extraordinary physiological effort involved in hatching) and the raise of temperature (PÉREZ et al., 1998ab). Organic contamination of water and spread of fungus caused losses of eggs during Al (MASON, 1977b; RHODES, 1981; CARRAL et al., 2004). As prevention of fungal diseases, CARRAL et al. (2004) recommend to maintain good water quality and removal of dead eggs. MASON (1977b) and RHODES (1981) described successful use of malachite green, which is not licensed today, to decrease egg mortalities during Al. CELADA et al. (2004) tested different doses and treatment frequencies of formaldehyde, hydrogen peroxide, sodium chloride and malachite green on eggs of signal crayfish (Pacifastacus leniusculus D.) during $\mathbf{A l}$.

KOUŘIL et al. (1998), HAMÁČKOVÁ and KOUŘIL (1997) recommend to successfully use the iodine-detergent preparation (Jodisol) instead of illegal malachite green during artificial incubation of different species of fish eggs.

The goal of our study was to establish the effect of egg bath (iodine-detergent preparation, Jodisol) and daily removal of dead eggs on hatching success and production of stage 2 juveniles using $\boldsymbol{A l}$ of eggs in the noble crayfish. 


\section{MATERIAL AND METHODS}

On June $3^{\text {rd }} 2004,25$ ovigerous females of crayfish Astacus astacus (mean total body length: $91.6 \pm 9.8 \mathrm{~mm}$, mean body weight: $23.9 \pm 8.7 \mathrm{~g}$ and mean pleopodal fecundity: $87 \pm 39.9$ eggs) were caught by baited sticks in the Světlohorská reservoir. Environmental conditions of the Světlohorská reservoir were described in detail by POLICAR and KOZÁK (2005). All caught females were transported in two polystyrene boxes ( $30 \mathrm{dm}^{3}$ capacity, $10 \mathrm{dm}^{2}$ of bottom surface, containing $25 \mathrm{~mm}$ layer of wet grass). All transported females were placed in one fibreglass trough with $1.5 \mathrm{~m}^{2}$ area and 25 plastic pipes as shelters. The eggs were removed and pooled from all females on June $4^{\text {th }}$. Females were stocked back into the Světlohorská reservoir after egg removal.

After removal, 1,800 eggs were stocked into eighteen jars. The embryonic development of removed eggs was assessed according to Celada et al. (1991). Eggs were detached in phase XII (pulsating heart appearance). Eggs were incubated in 1 liter polyethylene jars (flow $1 \mathrm{I} \cdot \mathrm{min}^{-1}$ ) (Figure 1). Jars were parts of a recirculation water system containing storage and filtration tank, pump, stand of jars made of 18 one liter jars and water distribution system (Figure 2). Each jar had $22.0 \mathrm{~cm}^{2}$ of bottom surface. Eggs were incubated in density 100 eggs.jar ${ }^{-1}=4.5$ eggs. $\mathrm{cm}^{-2}$. Dissolved oxygen and temperature were measured daily: temperature was $18.8 \pm 0.75^{\circ} \mathrm{C}$ and dissolved oxygen was $8.5 \pm 0.5 \mathrm{mg} . \mathrm{l}^{-1}$. The parameters of water quality $\left(\mathrm{pH}, \mathrm{NH}_{3}, \mathrm{NO}_{2}^{-}\right.$and $\left.\mathrm{NO}_{3}{ }^{-}\right)$were checked weekly on the $1^{\text {st }}, 8^{\text {th }}$ and $15^{\text {th }}$ day of $\boldsymbol{A I}$. During incubation, the parameters of water quality were: $\mathrm{pH}=7.6 \pm 0.2$, content of ammonium $=0.06 \pm 0.002 \mathrm{mg} . \mathrm{l}^{-1}$, nitrite $=0.0017 \pm 0.000$ 2 mg. $\mathrm{I}^{-1}$, nitrate $=0.2 \pm 0.02 \mathrm{mg} . \mathrm{I}^{-1}$.

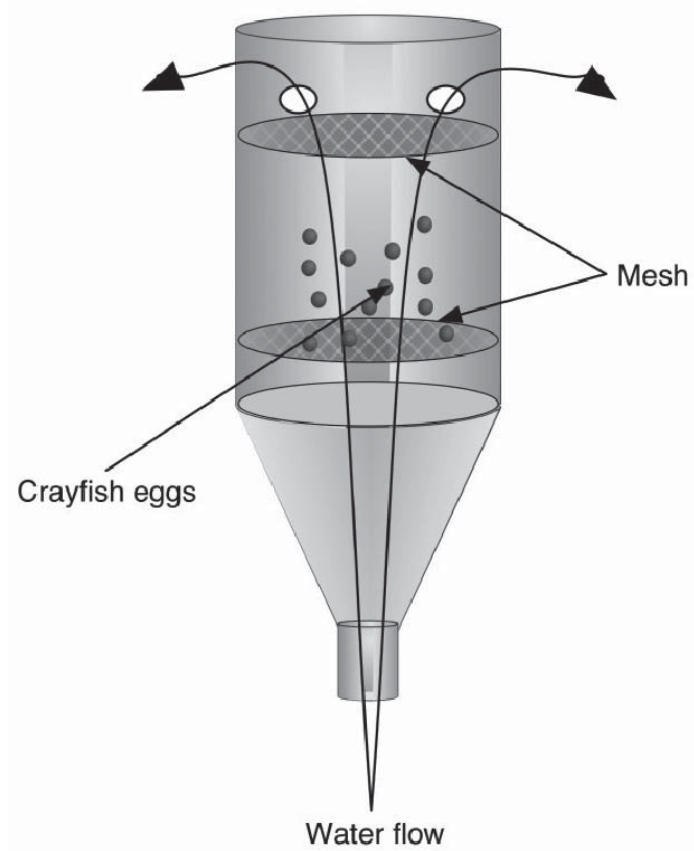

Figure 1

Detail of one liter jar.

\section{Figure 1}

Détail d'un flacon d'un litre. 


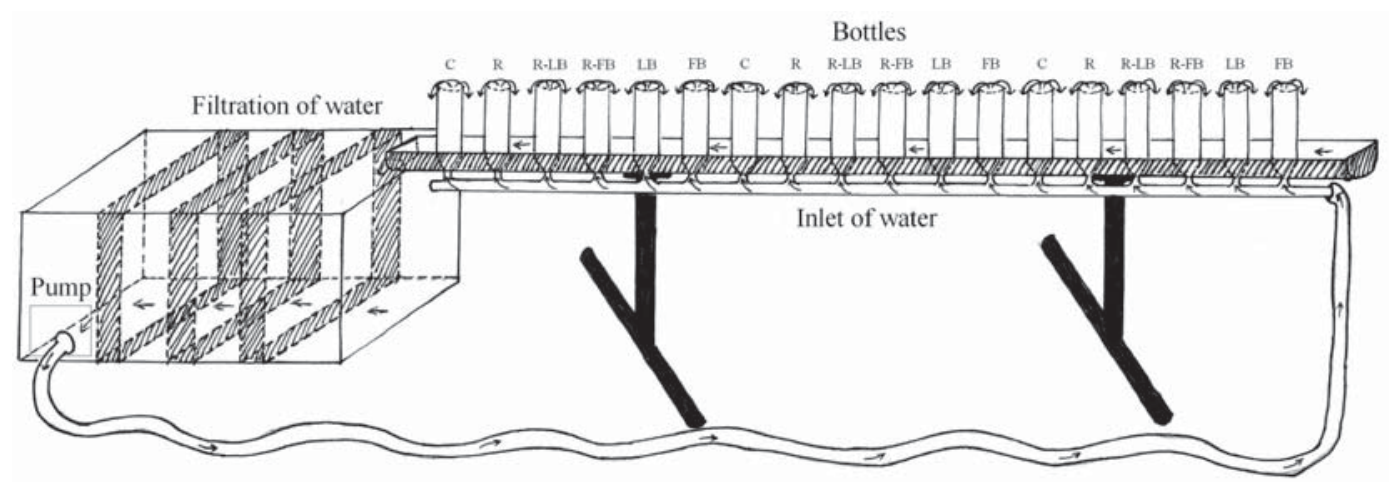

Figure 2

Description of the recirculation system.

\section{Figure 2}

Système de recyclage utilisé pour les expériences.

Six different treatments with three replicates were tested:

C: control group without removal of dead eggs and egg bath;

R: daily removal of dead eggs without egg bath;

R-LB: daily removal of dead eggs, low frequency of egg bath (once every five days);

R-FB: daily removal of dead eggs, frequent egg bath (once every three days);

LB: without removal of dead eggs, with low frequency of egg bath;

FB: without removal of dead eggs, with frequent egg bath.

Egg bath was performed by iodine-detergent preparation, Jodisol, dose $2 \mathrm{ml}^{. \mathrm{I}^{-1}}$ and with the exposition time of 2 minutes according to KOUŘIL et al. (1998). During removal of dead eggs, all eggs were taken from the jar to a flat saucer. Eggs were checked, dead eggs were removed and live eggs were put back into the jar. Daily egg mortality was observed in all treatments. At the end of $\boldsymbol{A l}$, productions of stage 1 and 2 juveniles were determined in separate jars for each treatment, respectively. Productions of stage 1 and 2 juveniles among each treatment were compared using ANOVA (Statgraphic, Tukey test, $P<0.05)$.

After the production of stage 2 juveniles, animals from all treatments were stocked into two rearing troughs, $1.5 \mathrm{~m}^{2}$ in each area, under controlled laboratory conditions. At the beginning of rearing, 600 stage 2 juveniles (initial density of 400 individuals in the stage 2 per $1 \mathrm{~m}^{2}$ of rearing area) were stocked in each trough. Juveniles were reared under the same conditions described by POLICAR and KOZÁK (2004) till the end of the $1^{\text {st }}$ growing season (September 29th). At the end of the rearing period, mean body length, weight and survival rate were measured as described by POLICAR and KOZÁK (2004). Growth and survival rate of juveniles from $\boldsymbol{A l}$ were compared to the normal hatched juvenile rearing by POLICAR and KOZÁK (2004).

\section{RESULTS}

First hatching was observed on June $20^{\text {th }}\left(\boldsymbol{A l} 17^{\text {th }}\right.$ day) and stage 2 on June $27^{\text {th }}$. Thus, hatching was observed after 16 days with $\boldsymbol{A l}$ and first moult (production of stage 2) of juveniles occurred after 23 days. 


\section{Table I}

Mean survival rates $(\% \pm$ SEM) of Astacus astacus eggs to hatching and to stage 2 juveniles for each treatment.

\section{Tableau I}

Taux de survie des œufs d'Astacus astacus à l'éclosion et au stade 2 juvéniles pour toutes les expériences.

\begin{tabular}{|c|c|c|}
\hline Treatment & Hatching (\%) & Success rate to stage 2 (\%) \\
\hline Control & $74.3 \pm 0.9 \mathrm{a}$ & $73.3 \pm 0.5 \mathrm{a}$ \\
\hline LB & $82.3 \pm 4.0 \mathrm{ab}$ & $80.3 \pm 4.0 \mathrm{ab}$ \\
\hline FB & $82.6 \pm 6.0 \mathrm{ab}$ & $81.0 \pm 5.7 \mathrm{ab}$ \\
\hline R-LB & $86.0 \pm 5.3 \mathrm{~b}$ & $83.3 \pm 4.9 \mathrm{~b}$ \\
\hline R & $86.3 \pm 6.0 \mathrm{~b}$ & $84.3 \pm 5.7 \mathrm{~b}$ \\
\hline R-FB & $86.6 \pm 5.9 \mathrm{~b}$ & $85.0 \pm 5.9 \mathrm{~b}$ \\
\hline
\end{tabular}

Different superscript shows significant differences of hatching rate and success rate to stage 2 between treatments (ANOVA; Tuckey test; $\mathrm{P}<0.05$ ).

The best hatching rate $(86.3 \pm 5.4 \%$ average, with minimum $86.0 \pm 5.3 \%$ and maximum $86.6 \pm 5.9 \%)$ and production of stage 2 juveniles $(84.2 \pm 5,4 \%$ average, with minimum $83.3 \pm 4.9 \%$ and maximum $85.0 \pm 5.9 \%)$ were observed in treatments $(R ; R-F B$ and R-LB), where dead eggs were removed daily. On the contrary, the lowest hatching rate $(74.3 \pm 0.9 \%)$ and production of stage 2 juveniles $(73.3 \pm 0.5 \%)$ were observed in the control group without manipulation (no removal of dead eggs and no egg bath). Treatments LB and FB did not show a significant difference in the hatching rate $(82.5 \pm 5.5 \%$ average, with minimum $82.3 \pm 4.0 \%$ and maximum $82.6 \pm 6.0 \%$ ) and production stage 2 juvenile $(80.7 \pm 5.3 \%$ average, with minimum $80.3 \pm 4.0 \%$ and maximum $81.0 \pm 5.7 \%)$ than others treatments (Table I). Daily cumulative survival rate of incubated eggs and juveniles in the different treatments are shown in Figure 3.

At the end of juvenile rearing, mean body length $(22.3 \pm 1.7 \mathrm{~mm}$ and $21.7 \pm 1.4 \mathrm{~mm}$, respectively), body weight $(278.6 \pm 55.9 \mathrm{mg}$ and $254.0 \pm 46.9 \mathrm{mg}$, respectively) and survival rate $(64.1 \pm 0.5 \%)$ were found in both rearing troughs. Similar growth and better survival of juveniles were observed using $\boldsymbol{A} \boldsymbol{I}$ in comparison to the normal hatched juveniles (POLICAR and KOZÁK, 2004).

\section{DISCUSSION}

After $\boldsymbol{A}$, a high hatching rate was observed in all treatments compared to the values attained by STREMPEL (1973) and CUKERZIS (1988) after similar long Al of Astacus astacus. On the contrary, MASON (1977b) achieved a better hatching rate (90-98\%) and success rate to stage 2 juveniles (88\%) in similar long $\boldsymbol{A l}$ of Pacifastacus leniusculus.

Good results in all treatments observed in the present experiment were probably due to the high quality of the water during $\boldsymbol{A l}$, which eminently influences survival of incubated eggs (MASON, 1977b; RHODES, 1981; CARRAL et al., 2004; PÉREZ et al., 1998b).

Al lasted a short period but according to CARRAL et al. (2004) and PÉREZ et al. (1998ab) included the big part of total egg losses. Most of the egg losses occurred in the control group, without any treatment. Egg bath by preparation Jodisol caused less egg losses than those which were noted in the control group, however without a significant difference. Three treatments, where dead eggs were removed daily (without reference to egg bath), showed significantly less egg losses than other treatments. 


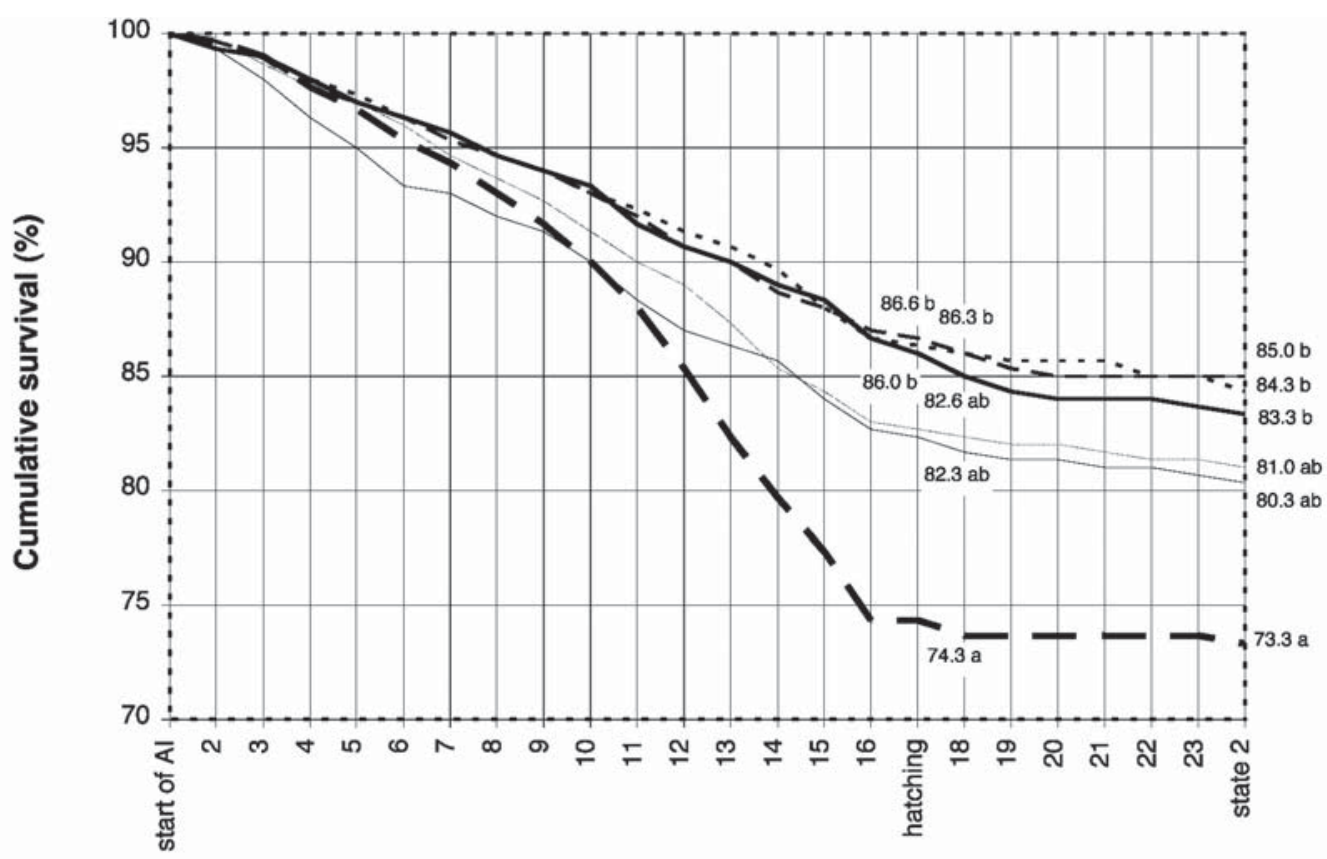

Days of artificial incubation

$-\mathrm{FB} \longrightarrow \mathrm{FB}-\mathrm{LB}---\mathrm{R}-\mathrm{FB} \cdots \cdot \mathrm{R}-\mathrm{R}$

\section{Figure 3}

Daily cumulative survival rate of eggs and juveniles during artificial incubation.

\section{Figure 3}

Taux de survie cumulé journalier des œufs et des juvéniles pendant l'incubation artificielle.

According to our results we agree with MASON (1977b), RHODES (1981) and CELADA et al. (2004) on the possibility to successfully use antifungal preparations to achieve a higher hatching success. CELADA et al. (2004) successfully used antifungal preparations under lower egg density $\left(2.2\right.$ eggs. $\left.\mathrm{cm}^{-2}\right)$ and higher egg density $(6.6$ eggs. $\left.\mathrm{cm}^{-2}\right)$. High survival rate was observed under low egg density $\left(2.2\right.$ eggs. $\left.\mathrm{cm}^{-2}\right)$ even without antifungal preparation, like in CARRAL et al. (1988, 1992), PÉREZ et al. (1998ab, 1999; 2003); CELADA et al. (2000; 2001; 2004). Under higher egg density (6.6 eggs. $\left.\mathrm{cm}^{-2}\right)$, high efficiency was obtained with the administration of $4,500 \mathrm{ppm}$ of formaldehyde or $15 \mathrm{ppm}$ of malachite green. However, the use of malachite green on edible animal species has been banned in the European Union by means of the regulation 2377/90/EEC (CELADA et al., 2004).

On the other side, our results showed that removal of dead eggs had a higher effect to protect incubated eggs. This could be caused by the low concentration or short exposition time of the antifungal preparation Jodisol. A lower dose and a shorter exposition time of Jodisol than the values recommended by KOUŘIL et al. (1998), HAMÁČKOVÁ and KOUŘIL (1997) were used for incubation of fish eggs.

Periodical removal of dead eggs is effective in protecting egg incubation against fungi (CARRAL et al., 2004). CARRAL et al. (2004) used a lower egg density (2.2 eggs.cm-2) however recommended using a higher egg density for a more exclusive demonstration of 
the effect of dead egg removal on the efficiency of egg incubation. The higher efficiency of the methods that use the removal of dead eggs compared to the egg bath by Jodisol could be due to the higher egg density in our study. Most likely the removal of dead eggs helped to decrease the fungal disease propagation. On the contrary, the selected dose and exposition time of Jodisol were insufficient to protect the incubated eggs against fungi diseases. In the future, it will be important to choose a higher dose or exposition time of Jodisol to ensure the vitality of incubated eggs.

Use of $\boldsymbol{A} \boldsymbol{l}$ in crayfish reproduction had no negative effects on the achieved growth and survival of juvenile at the end of their rearing (SÁEZ-ROYUELA et al., 1995). These authors found a lower survival rate of signal crayfish juveniles from artificial incubation during the first 80 days of their rearing with no significant differences in survival and growth rates at the end of their rearing compared to those from maternal incubation. Our performed $\boldsymbol{A} \boldsymbol{I}$ had no negative effect on the growth and survival rate of juveniles at the end of their rearing, too. Prematurely separated stage 2 juveniles in signal crayfish influenced lower growth but no lower survival rate than normal juveniles (Mason, 1977a).

Removal of dead eggs was a more effective method for increasing the hatch rate than egg bath during the short $\boldsymbol{A I}$. It may be concluded according to our results that the use of antifungal preparations can protect incubation eggs against fungal diseases. Therefore we recommend the search for other applications of antifungal bathing to be used during $\boldsymbol{A} \boldsymbol{l}$ of crayfish eggs.

\section{ACKNOWLEDGEMENTS}

This investigation was supported by the Ministry of Education of the Czech Republic, project no. MSM 6007665809 and by the Ministry for Agriculture of the Czech Republic, project no. NAZV QF 3028. Authors of this paper gratefully thank colleague Petra Vorlíčková for the translation of the French abstract.

\section{REFERENCES}

CARRAL J.M., CELADA J.D., GAUDIOSO V.R., TEMIÑO C., FERNÁNDEZ R., 1988. Artificial incubation improvement of crayfish eggs (Pacifastacus leniusculus Dana) under low temperatures during embryonic development. Freshwater Crayfish, 7, 239-250.

CARRAL J.M., CELADA J.D., GONZÁLEZ J., GAUDIOSO V.R., FERNÁNDEZ R., LÓPEZBAISSÓN C., 1992. Artificial incubation of crayfish eggs (Pacifastacus leniusculus Dana) from early stages of embryonic development. Aquaculture, 104, 261-269.

CARRAL J.M., SÁEZ-ROYUELA M., CELADA J.D., PÉREZ J.R., MELENDRE P.M., AGUILERA A., 2003. Advantages of artificial reproduction techniques for whiteclawed crayfish (Austropotamobius pallipes Lereboullet). Bull. Fr. Pêche Piscic., 370-371, 181-184.

CARRAL J.M., PÉREZ J.R., CELADA J.D., SÁEZ-ROYUELA M., MELENDRE P.M., AGUILERA A., 2004. Effects of dead egg removal frequency on stage 2 juvenile production in artificial incubation of Austropotamobius pallipes Lereboullet. Bull. Fr. Pêche Piscic., 372-373, 425-430.

CELADA J.D., CARRAL J.M., GAUDIOSO V.R., CONSUELO T., FERNÁNDEZ R., 1988. Effects of thermic manipulation throughout egg development on the reproductive efficiency of the freshwater crayfish (Pacifastacus leniusculus Dana). Aquaculture, 72, 341-348.

CELADA J.D., CARRAL J.M., GONZÁLEZ J., 1991. A study on the identification and chronology of the embryonic stages of the freshwater crayfish Austropotamobius pallipes (Lereboullet, 1858). Crustaceana, 61 (3), 225-232. 
CELADA J.D., GONZÁlEZ J., CARRAL J.M., FERNÁNDEZ R., PÉREZ J.R., SÁEZROYUELA M., 2000. Storage and transport of embryonated eggs of the signal crayfish Pacifastacus leniusculus. N. Am. J. Aquac., 62, 308-310.

CELADA J.D., CARRAL J.M., PÉREZ J.R., SÁEZ-ROYUELA, MUÑOZ C., 2001. Successful storage and transport of eggs of the white-clawed crayfish (Austropotamobius pallipes Lereboullet). Aquaculture International, 9, 269-276.

CELADA J.D., CARRAL J.M., SÁEZ-ROYUELA M., MELENDRE P.M., AGUILERA A., 2004. Effect of different antifungal treatments on artificial incubation of the astacid crayfish (Pacifastacus leniusculus Dana) eggs. Aquaculture, 239, 249-259.

CUKERZIS J.M., 1988. Astacus astacus in Europe. In: Freshwater Crayfish: Biology, Management and Exploitation, (eds HOLDICH D.M. \& LOWERY R.S.), Croom Helm, London, 309-340.

CUKERZIS J.M., 1989. Rečnyje raky / Freshwater Crayfish. Monografija, Akademija nauk litovskoj SSR, Vilnius, 135 p., (in Russian).

CUKERZIS J.M., SHESHTOKAS A.L., TERENTYEV A.L., 1978. Method for accelerated artificial breeding of crayfish juveniles. Freshwater Crayfish, 4, 452-458.

JÄRVENPÄÄ T., ILMARINEN P., 1995. Artificial incubation of crayfish eggs on moving tray. Freshwater Crayfish, 8, 716.

GONZÁLEZ J., CARRAL J.M., CELADA J.D., SÁEZ-ROYUELA M., GAUDIOSO V.R., FERNÁNDE R., LÓPEZ-BAISSÓN C., 1993. Management of crayfish eggs (Pacifastacus leniusculus Dana) for intensification of juvenile production. Freshwater Crayfish, 9, 144-146.

HAMÁČKOVÁ J., KOUŘIL J., 1997. Laboratory tests of a sensitivity of eight fish species eggs upon the antifungal baths in malachite green and iodine-detergent (Wescodyne and Jodisol) solutions. Pol. Arch. Hydrobiol., 44, 247-260.

KOUŘIL J., HAMÁČKOVÁ J., KOZÁK, P., 1998. Tolerance of tench Tinca tinca (L.) eggs to baths in malachite green and iodine-deterent preparations. Pol. Arch. Hydrobiol., 45, 439-446.

KÖKSAL G., 1988. Astacus leptodactylus in Europe. In: HOLDICH D.M. and LOWERY R.S. (eds), Freshwater Crayfish: Biology, Management and Exploitation, Croom Helm, London, 365-400.

MASON J.C., 1977a. Reproductive efficiency of Pacifastacus leniusculus Dana in culture. Freshwater Crayfish, 3, 101-117.

MASON J.C., 1977b. Artificial incubation of crayfish eggs (Pacifastacus leniusculus Dana). Freshwater Crayfish, 3, 119-132.

MATTHEWS M., REYNOLDS J.D., 1995. The in vitro culture of crayfish eggs using a recirculating airlift incubator. Freshwater Crayfish, 8, 300-306.

PÉREZ J.R., CARRAL J.M., CELADA J.D., SAEZ-ROYUELA M., ROMERO M.P., 1998a. Effects of different thermal treatments throughout the embryonic development on the artificial incubation efficiency of crayfish (Austropotamobius pallipes Lereboullet) eggs. Control of the embryogenetic duration and implications for commercial production. Invertebrate Reproduction and Development, 34 (2-3), 253-258.

PÉREZ J.R., CARRAL J.M., CELADA J.D., SAEZ-ROYUELA M., ROMERO M.P., 1998b. Effects of stripping time on the success of the artificial incubation of white-clawed crayfish, Austropotamobius pallipes (Lereboullet), eggs. Aquaculture Research, 29, 389-395. 
PÉREZ J.R., CARRAL J.M., CELADA J.D., SAEZ- ROYUELA M., MUÑOZ C., ANTOLÍN J.I., 1999. The possibilities for artificial incubation of white-clawed crayfish (Austropotamobius pallipes Lereboullet) eggs. Comparison between maternal and artificial incubation. Aquaculture, 170, 29-35.

PÉREZJ.R., CELADA J.D., GONZÁLEZJ., CARRALJ.M., SÁEZ-ROYUELA M., FERNÁNDEZ R., 2003. Duration of egg storage at different temperatures in the astacid crayfish Pacifastacus leniusculus: critical embryonic phase. Aquaculture, 219, 347-354.

POLICAR T., SIMON V., KOZÁK P., 2004. Egg incubation in the noble crayfish (Astacus astacus L.): the effect of controlled laboratory and outdoor ambient condition on hatching success, growth and survival rate of juveniles. Bull. Fr. Pêche Piscic., 372373, 411-423.

POLICAR T., KOZÁK P., 2005. Comparison of trap and baited stick catch efficiency for noble crayfish (Astacus astacus L.) in the course of the growing season. Bull. Fr. Pêche Piscic., 376-377, 675-686.

REYNOLDS J.D., CELADA J. D., CARRAL J.M., MATTHEWS M.A., 1992. Reproduction of astacid crayfish in captivity - current developments and implications for culture, with special reference to Ireland and Spain. Invertebrate Reproduction and Development, 22, 253-266.

RHODES C.P., 1981. Artificial incubation of the crayfish Austropotamobius pallipes (Lereboullet). Aquaculture, 25, 129-140.

SÁEZ-ROYUELA M., CARRAL J.M., CELADA J.D., MUÑOZ C., 1995. Effects of management on survival and growth of Stage 2 juvenile freshwater signal crayfish (Pacifastacus leniusculus Dana) under laboratory conditions. Aquaculture, 133, 123-133.

STREMPEL K., 1973. Edelkreserbrutung in Zuger-Glasern und Anfutterung der Krebsbrut. Freshwater Crayfish, 1, 233-237 (in German with English abstract).

TAUGBØL T., SKURDAL J., 1990a. Reproduction, moulting and mortality of female noble crayfish, (Astacus astacus L.,1858), from five Norwegian populations subjected to indoor culture conditions (Decapoda, Astacoidea). Crustaceana, 58, 113-23.

TAUGBØL T., SKURDAL J., 1990b. Effect of density on brood size in noble crayfish, Astacus astacus L., subjected to indoor rearing conditions. Aquaculture and Fisheries Management, 21, 17-23. 